\title{
Response of brown sarson (Brassica campestris var. brown sarson) to integrated nutrient management in mid hill conditions of Himachal Pradesh
}

\author{
AMARDEEP SINGH BRAR*, PARKASH SINGH SIDHU AND GURMEET SINGH DHILLON \\ Krishi Vigyan Kendra, BHATINDA(PUNJAB) INDIA \\ (Email:goodbrar@gmail.com)
}

\begin{abstract}
A field experiment was conducted during Rabi 2011-12 at the experimental farm of Department of Agronomy, Forages and Grassland Management CSKHPKV, Palampur Himachal Pradesh to study the "Response of brown sarson (Brassica campestris var. brown sarson) to integrated nutrient management in mid hill conditions of Himachal Pradesh". The treatments comprising of all possible combinations of three biofertilizers viz., Azotobacter, Azotobacter + PSB and no inoculation and four fertility levels viz., 100\% RDF, FYM 5.0 t ha ${ }^{-1}+50 \%$ RDF, Vermicompost 5.0 t ha ${ }^{-1}+50 \%$ RDF and control were tested in Factorial Randomized Block Design, replicated three times. Significantly highest plant height was recorded with the application of Azotobacter + PSB over Azotobacter alone and no inoculation at 90,120 DAS and at harvest. Among different fertility levels, application of 100 per cent RDF being statistically at par with vermicompost $5.0 \mathrm{t} \mathrm{ha}^{-1}+50 \%$ RDF produced significantly taller plants as compared to other treatments. Results revealed that growth, yield attributes, seed and straw yields of brown sarson were significantly increased with the application of biofertilizers and different fertility levels over control. The treatment receiving Azotobacter + PSB significantly increased the seed and straw yields followed by Azotobacter and no inoculation. Effect of fertility levels on seed and straw yields showed that 100 per cent RDF resulted in significantly higher seed and straw yield as compared to other fertility levels and control treatment. However, 100 per cent RDF treatment remained at par with vermicompost 5.0 tha $^{-1}+50 \%$ RDF. The application of biofertilizers and fertility levels could not exhibit any significant effect on harvest index. The increase in seed yield with Azotobacter + PSB was $20.3 \%$ over Azotobacter alone.
\end{abstract}

Key Words : Bio-fertilizer, Rapeseed, Siliqua, Vermicompost, Treatment, Straw yield

View Point Article : Brar, Amardeep Singh, Sidhu, Parkash Singh and Dhillon, Gurmeet Singh (2016). Response of brown sarson (Brassica campestris var. brown sarson) to integrated nutrient management in mid hill conditions of Himachal Pradesh. Internat. J. agric. Sci., 12 (2) : 319 325, DOI:10.15740/HAS/IJAS/12.2/319-325.

Article History : Received : 03.03.2016; Revised : 22.03.2016; Accepted : 18.05.2016

* Author for correspondence 